\title{
Mechanism of Corrosion in Production Wells using Stainless Steel: Review
}

\section{Amosu C.O.}

\begin{abstract}
It is essential for the designers, engineers and field operators, who designs and fabricates to be duly mindful of corrosion so as to enjoy undisturbed production, since most field materials are subjected to corrosion. This will prolong the commercial existence of production facilities. This paper provides an all-round review of challenges of corrosion while producing and proffers antidotes. The mechanism of corrosion was studied with the different kinds of corrosion that is experience in the Petroleum industry.
\end{abstract}

Keywords: Corrosion, Mechanism, Production, Wells, Steel, Rate

\section{INTRODUCTION}

Corrosion is a process that is natural which changes the state of a metal into the form that has chemical stability like as sulphide, hydroxide, or oxide. Its reaction looks like the one which takes place in a battery. Considering steel material in an acidic environment, at the anode, the iron dissolves and at the cathode, hydrogen is formed. An electrical path (e.g., water) is required.

$$
\mathrm{Fe}(\mathrm{s})+2 \mathrm{H}_{2} \mathrm{O}(\mathrm{l}) \longrightarrow \mathrm{Fe}(\mathrm{OH})_{2}(\mathrm{aq})+\mathrm{H}_{2}(\mathrm{~g}) \text {. }
$$

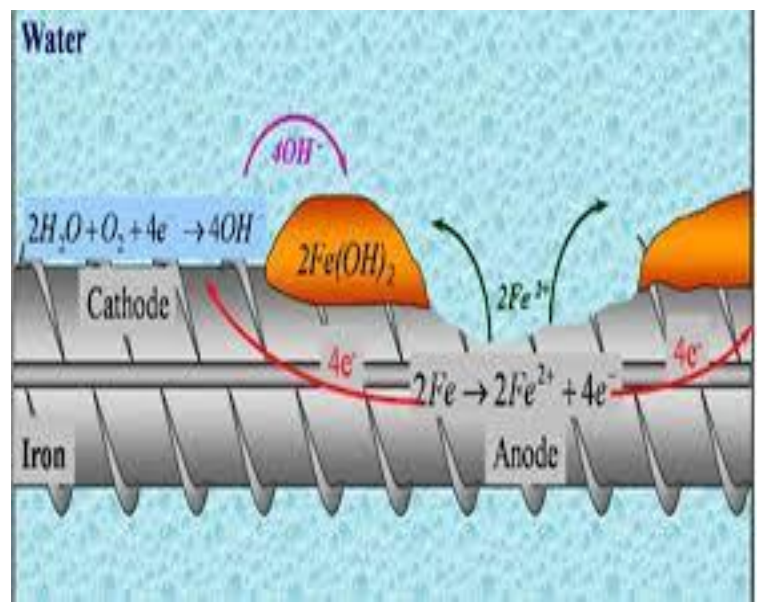

Manuscript received on 05 April 2021 | Revised Manuscript received on 18 April 2021 | Manuscript Accepted on 15 May 2021 | Manuscript published on 30 May 2021.

* Correspondence Author

Amosu C.O.*, Department of Mineral and Petroleum Engineering, Yaba College of Technology, Yaba. Email: cyril.amosu@yabatech.edu.ng

(C) The Authors. Published by Lattice Science Publication (LSP). This is an open access article under the CC-BY-NC-ND license (http://creativecommons.org/licenses/by-nc-nd/4.0/)
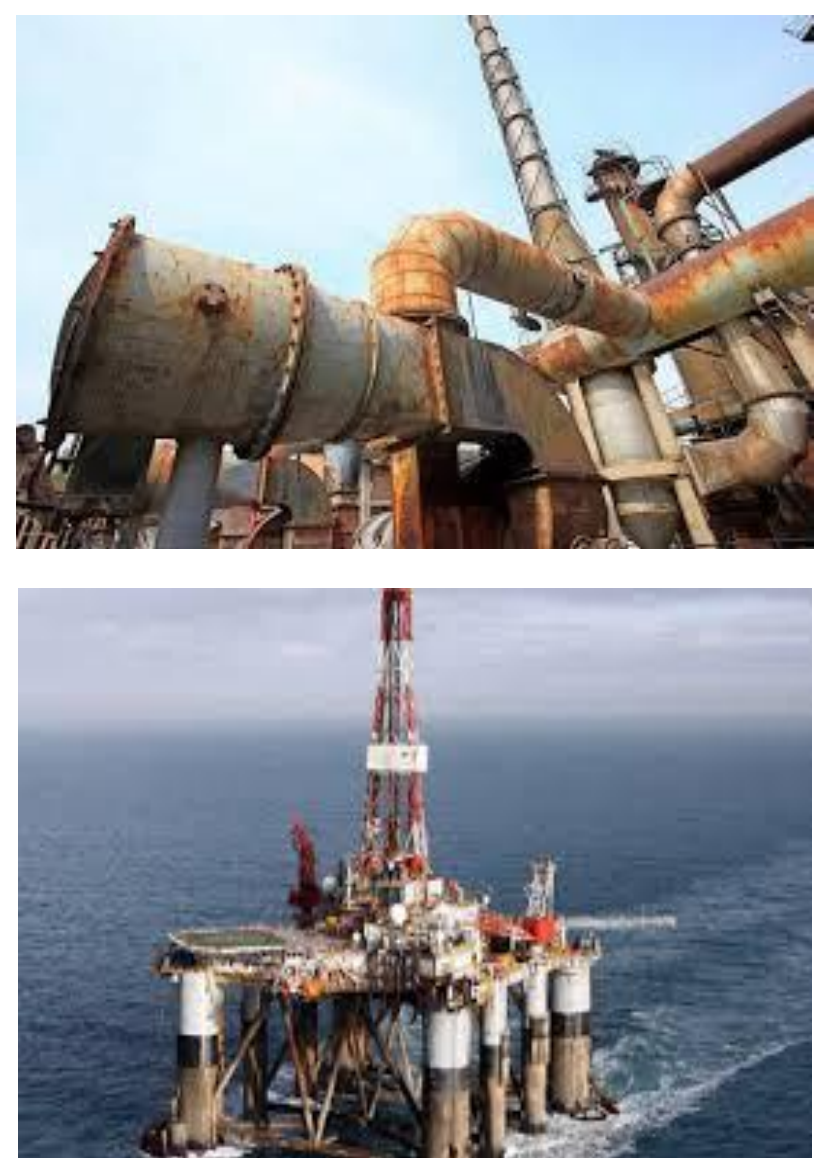

Figure 1: Mechanism of Corrosion and the environment it occurs (scib.azhar.live, gibsonstainless.com/ and capex.com.ng).

Corrosion has damaging attack on a material by reacting with in the environment (Roberge, 2000) and an inherent automatic hazard connected with production and transportation facilities in the petroleum industry (Kermani and Smith, 1997). Corrosion possesses broad consequences on the integrity of materials used in the oil and gas sector. Such operations include exploration, development, production, transportation and refinery. Corrosion of steel takes place at relative humidity range of about $80 \%$ and temperature range of about $32^{\circ} \mathrm{F}$ (TERESA, 2013).Corrosion worsens in aggressive surroundings (i.e., Saline, Sulphide, and/or acidic medium) with high temperatures and high pressures (HPHT) are situations to be confronted by materials in several production wells. As such, the facilities and control for corrosion used under such tough situations and places must be very dependable due to the high cost of maintenance or repair in inaccessible locations.

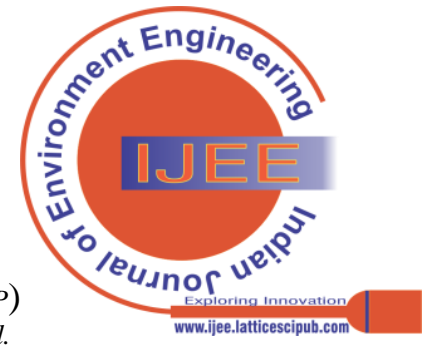




\section{Types of Corrosion}

Corrosion is grouped into eleven classes based on the nature of attack and the kind of surrounding of exposure.

\section{a) General or Uniform corrosion:}

It is the commonest kind of corrosion. Examples include rusting of: underground pipelines, submerged materials and steel bridges. Its control is mostly by painting the surface or using layers of sacrificial metal like steel and zinc.

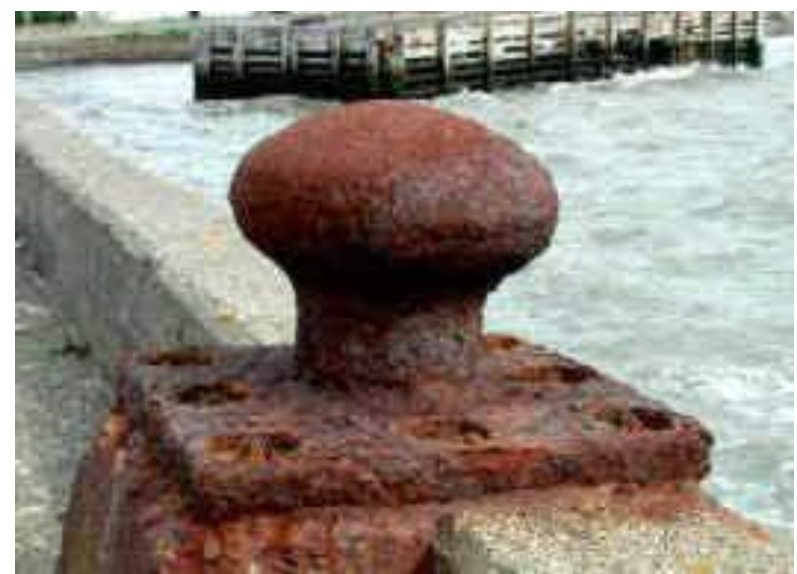

Figure 2: Instance of general or uniform corrosion (nace.org)

\section{b) Pitting Corrosion:}

It is a type of corrosion that occurs in carbon and lowalloy steels with scaling tendency at slow speed, $\mathrm{CO}_{2}$ partial pressure and increasing temperatures of dew in oil or gas production well.
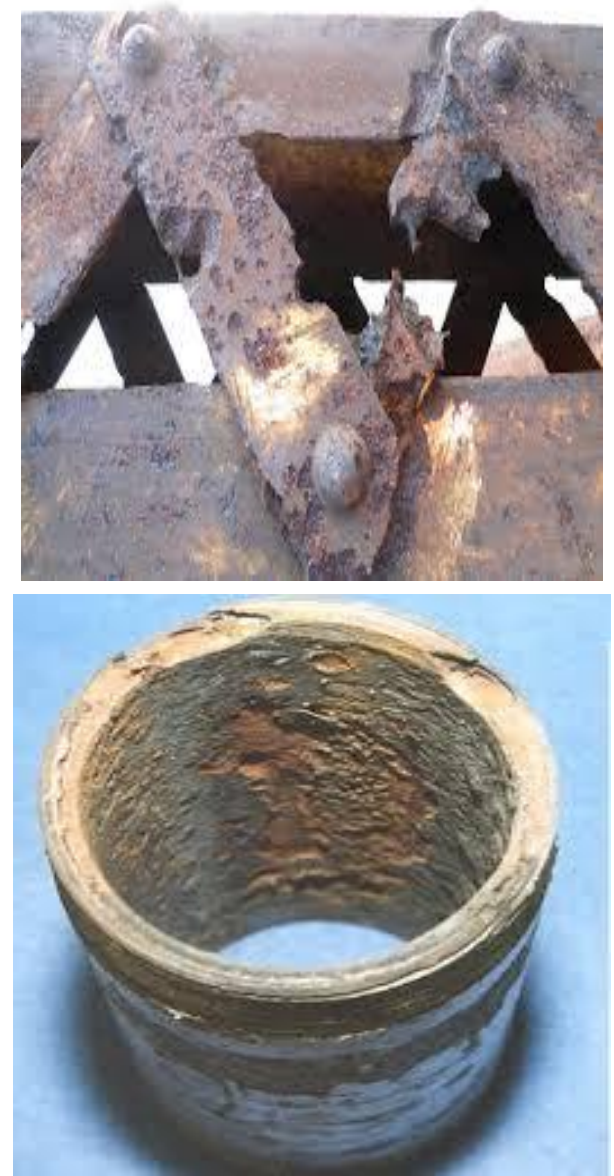

Retrieval Number:100.1/ijee.A1806051121

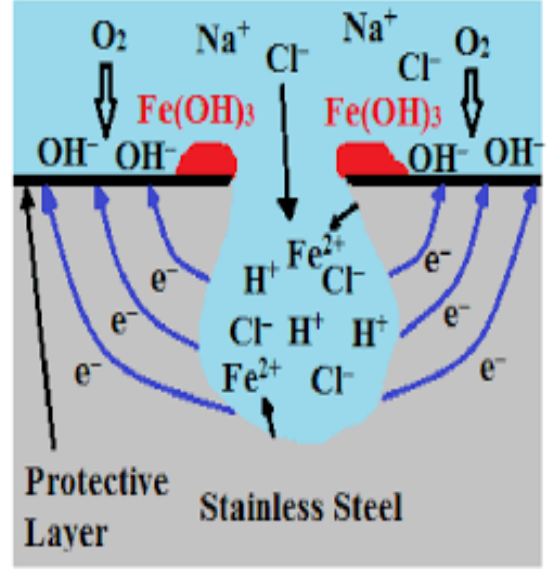

Figure 3: Instances of Pitting Corrosion (webwormcpt)

\section{c) Erosion corrosion:}

It is a corrosion that takes place by removing the passive layer of products continuously from the walls of the pipe and its accessories (Popoola et al. 2013).

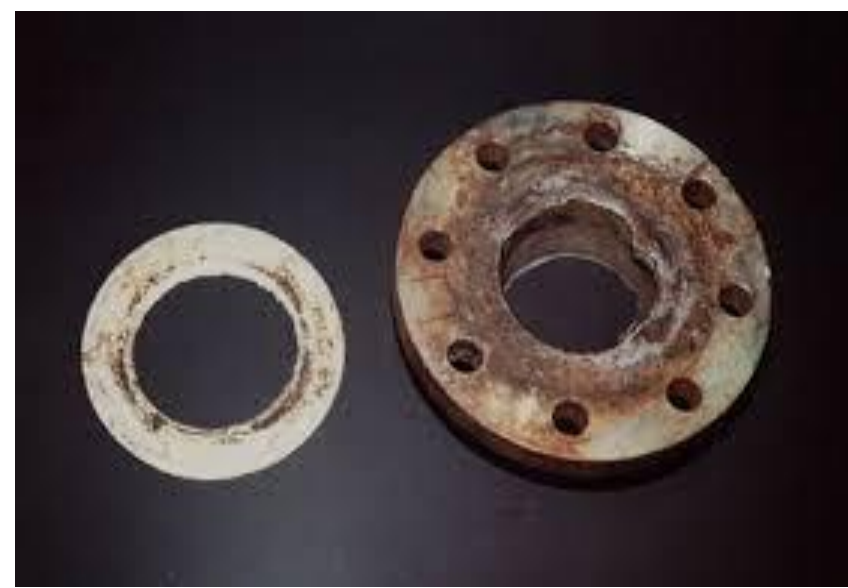

Figure 4: Instance of Erosion corrosion (arab-oilnaturalgas.com)

\section{d) Stress corrosion Cracking:}

This is a type of corrosion that is localized causing cracks and breakages in metallic materials simultaneously from the action of tensile stress and corrosion itself.
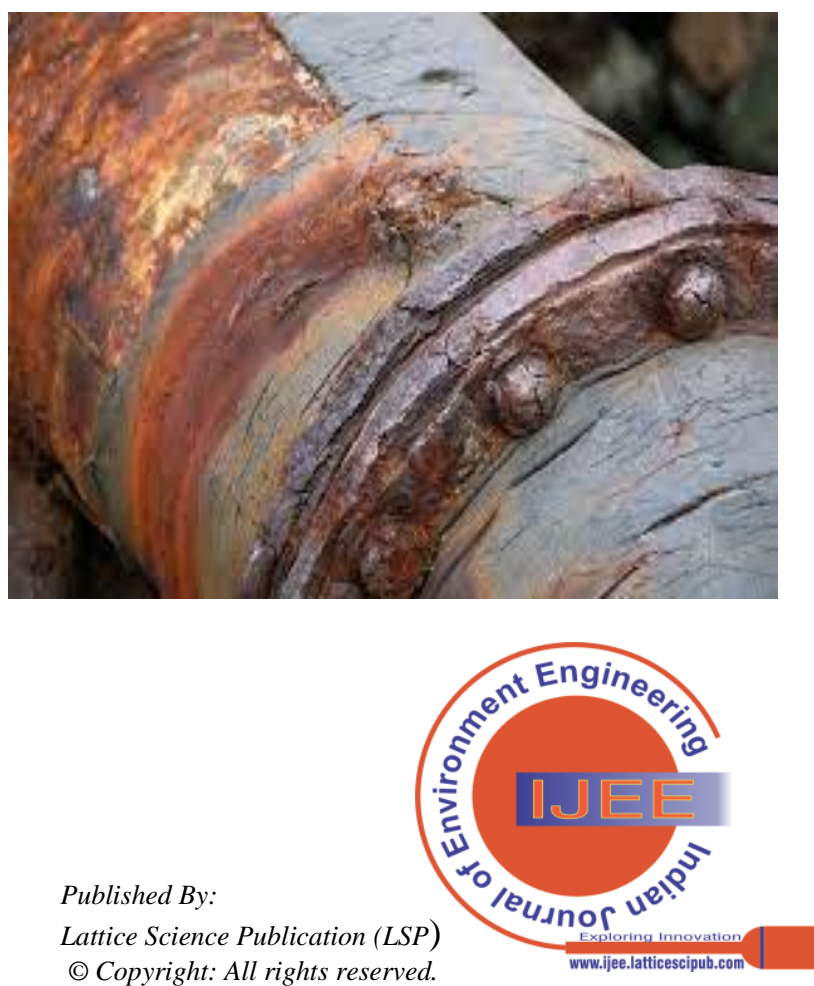


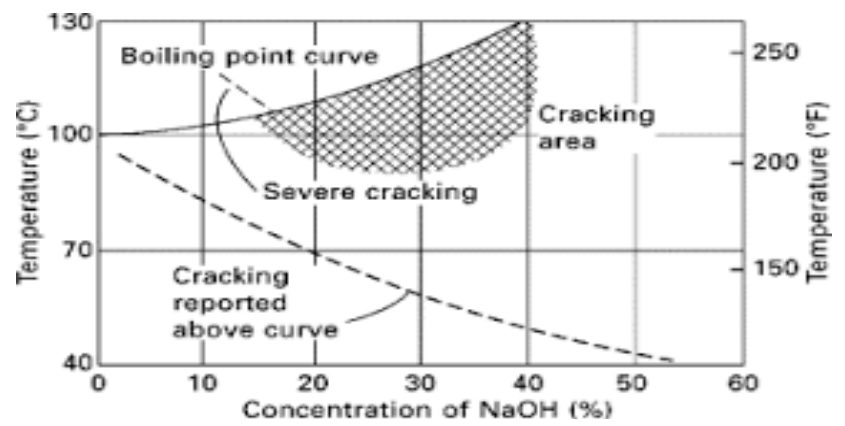

Figure 5: Instance of Stress corrosion cracking (pipelinejournal.net)

\section{e) Oxygen Corrosion:}

It is a kind of corrosion that occur in productions well caused by fluids from casing , open hatches, leaking pump seals and process vents. Oxygen speeds up the damage of metal, anodically as a depolarizer and as an electron acceptor in cathodic reactions, (Weeter, 1965).

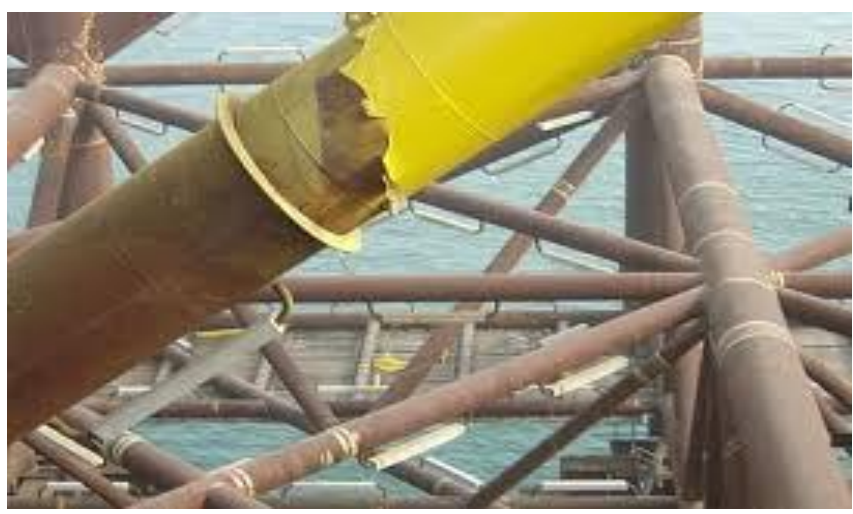

Figure 6: Instance of Oxygen Corrosion (ipdlabservices.co.uk).

\section{f) Galvanic Corrosion:}

It is the kind of corrosion that occurs from the exposure of two different metallic materials that has differing electrochemical potential in an electrolytic medium. According to Nalli, 2010, the metallic material with the less or the most negative electrochemical potential becomes the anode and starts corroding.

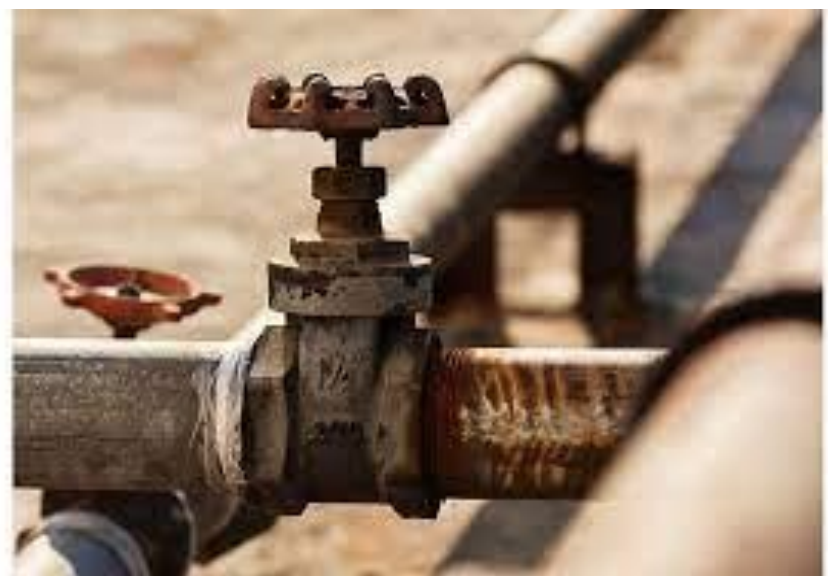

Figure 7: Instance of Galvanic Corrosion (corrosionpedia.com)

\section{g) Crevice Corrosion:}

This is the type of corrosion which is localized and occurs in places that have narrow clearances, gap or crevices in the metal making room for fluid stagnancy. Roberge,
2000 posited that it is caused by the differences in concentration of corrodents over a metal surface.
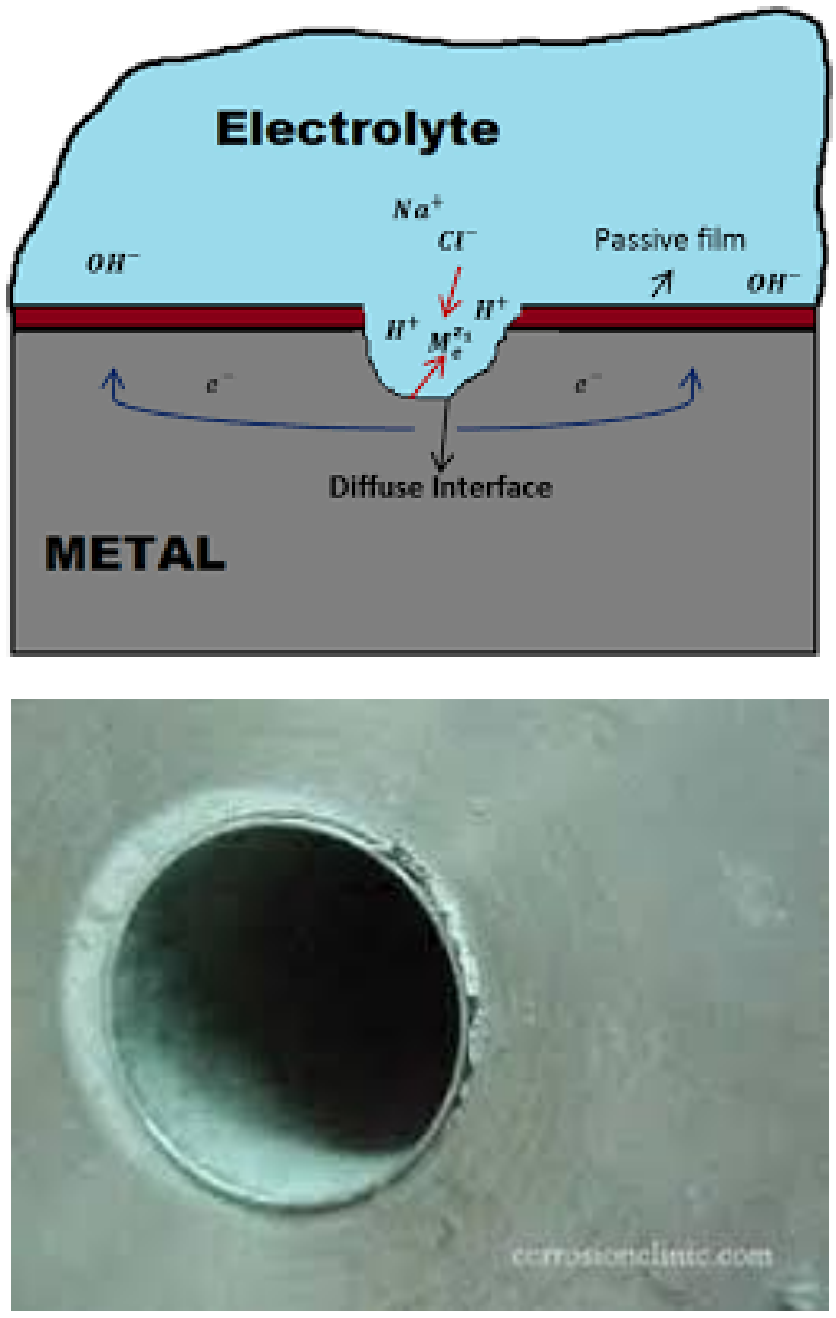

Figure 8: Instance of crevice corrosion (corrosionclinic.com)

\section{h) Mesa Attack:}

This is an unstable protective carbonate film formed from corrosion that takes place in fluid flow with low-tomedium. TERESA, 2013 confirmed that an exposed area operates as an anode of a galvanic cell while the filmcovered areas operate as the cathode.

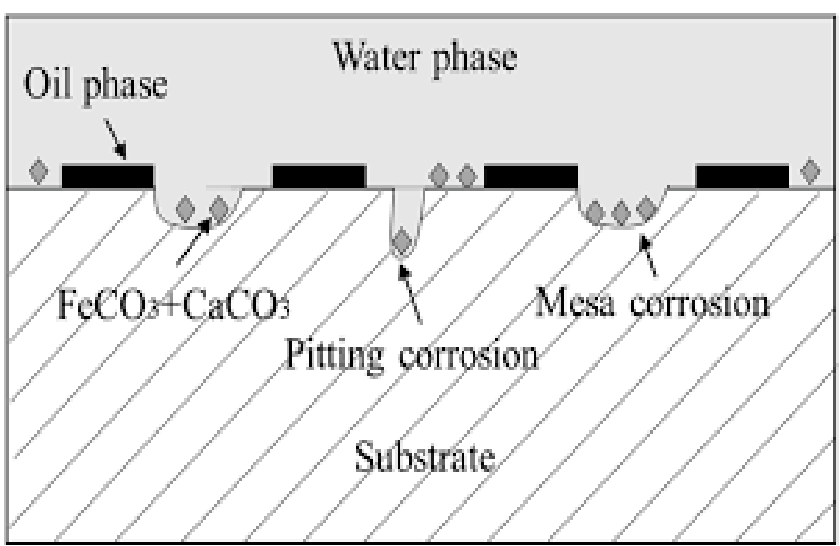

Published By:

Lattice Science Publication (LSP)

C Copyright: All rights reserved.

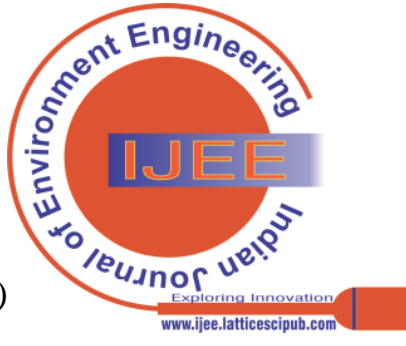



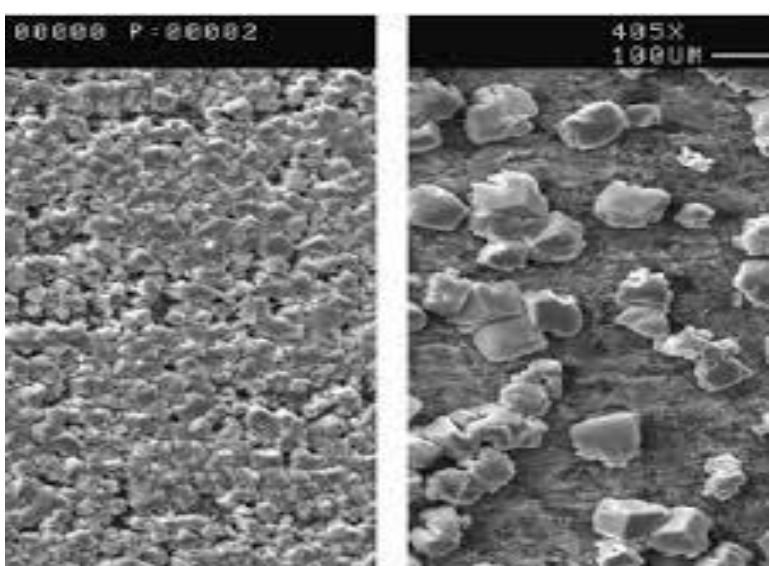

Figure 9: Instance of Crevice Corrosion (mdpi.com and researchgate.net)

\section{i) Hydrogen Embrittlement:}

This is the type of corrosion that occur metallic alloys like low-alloy steels and carbon steel with atomic hydrogen which harshly depreciates the fracture resistance of its strength in solid solution especially during manufacturing operations and environmental exposure.

$$
\begin{aligned}
& \mathrm{H}^{+}(\mathrm{aq})+\mathrm{le}-\longrightarrow \mathrm{H} \\
& \mathrm{H}+\mathrm{H} \longrightarrow \mathrm{H}_{2}(\mathrm{~g})
\end{aligned}
$$
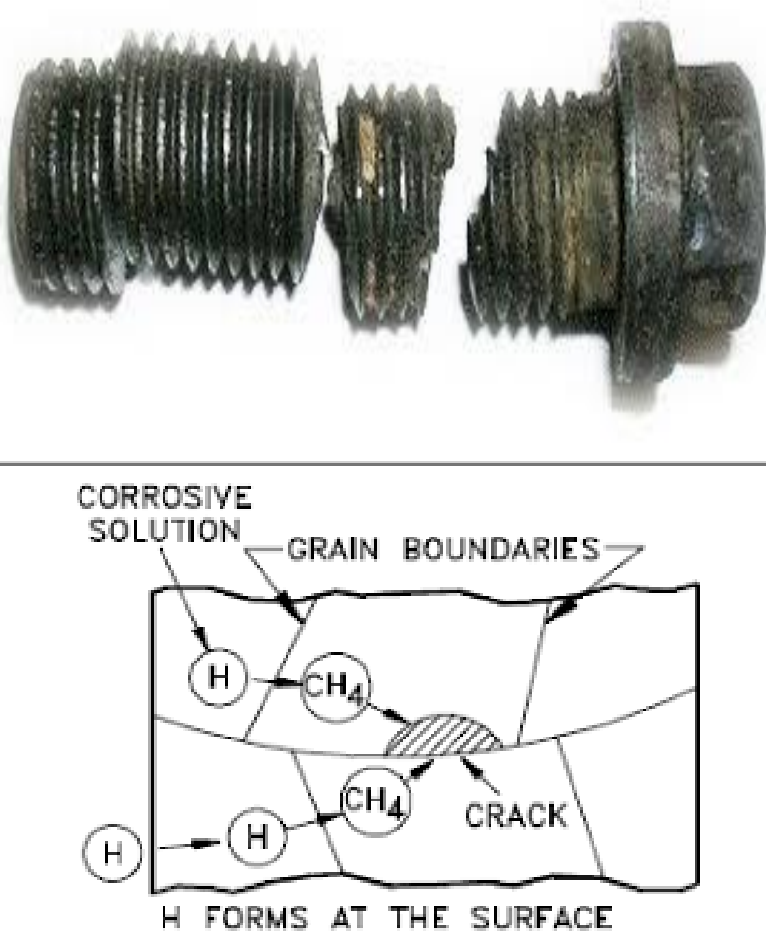

Figure 10: Instance of Hydrogen Embrittlement (boulonsplus.net and engineer-educators.com)

j) Sulphide Stress Cracking (Sour Corrosion):

This is a kind of corrosion that happens biologically in biogenic formations from the actions of microbes or sulphate reducing bacteria (SRB) which reduces existing sulphate ions to $\mathrm{H}_{2} \mathrm{~S}$ gas. TERESA, 2013 contributed that one of the source of bacterial contamination of aquifers are introduced through water injection that is not adequately treated.
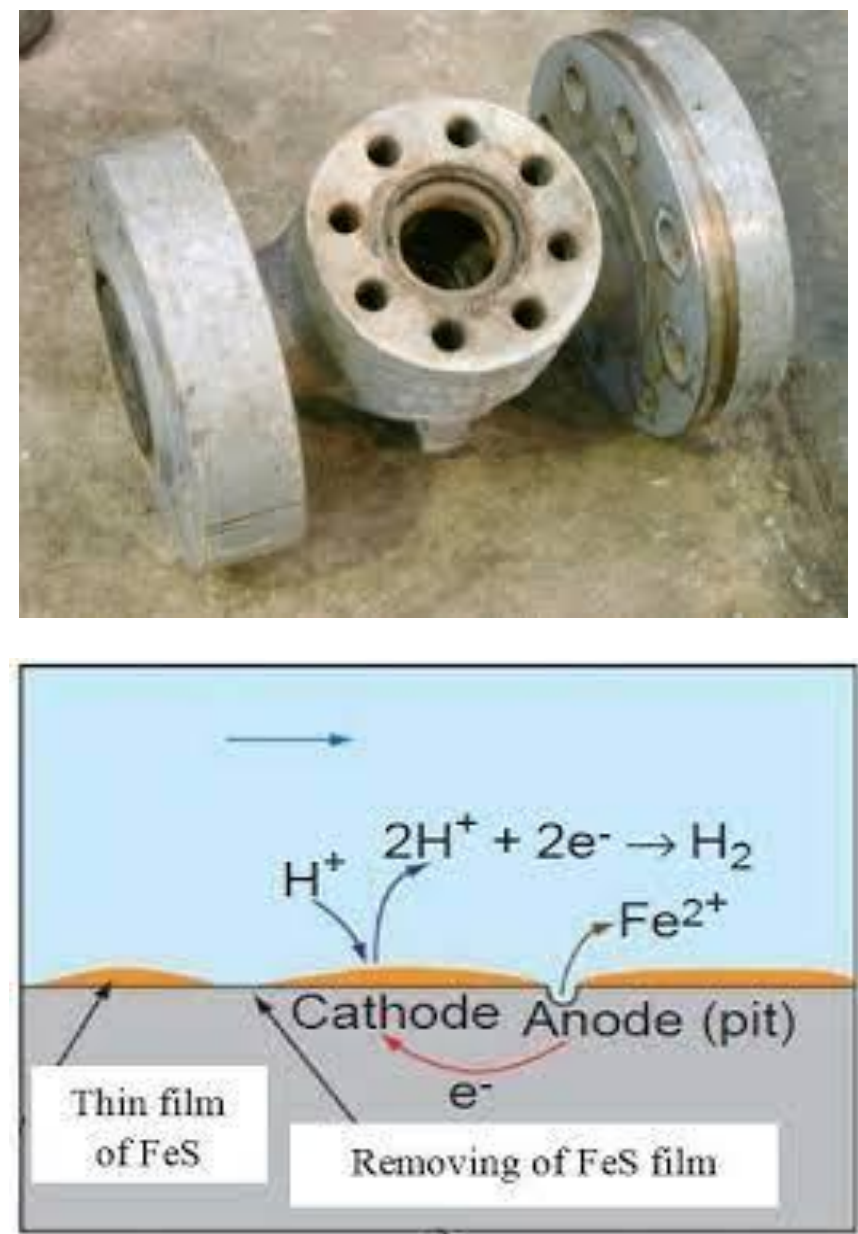

Figure 11: Instance of Sulphide Stress Cracking (sciencedirect.com and researchgate.net)

k) $\quad \mathrm{CO}_{2}$ Corrosion (Sweet Corrosion):

It is a kind of corrosion which involves dissolution of $\mathrm{CO}_{2}$ in an aqueous phase promoting reaction electrochemically between the steel and this contacting aqueous phase (Dugstad, 1992).
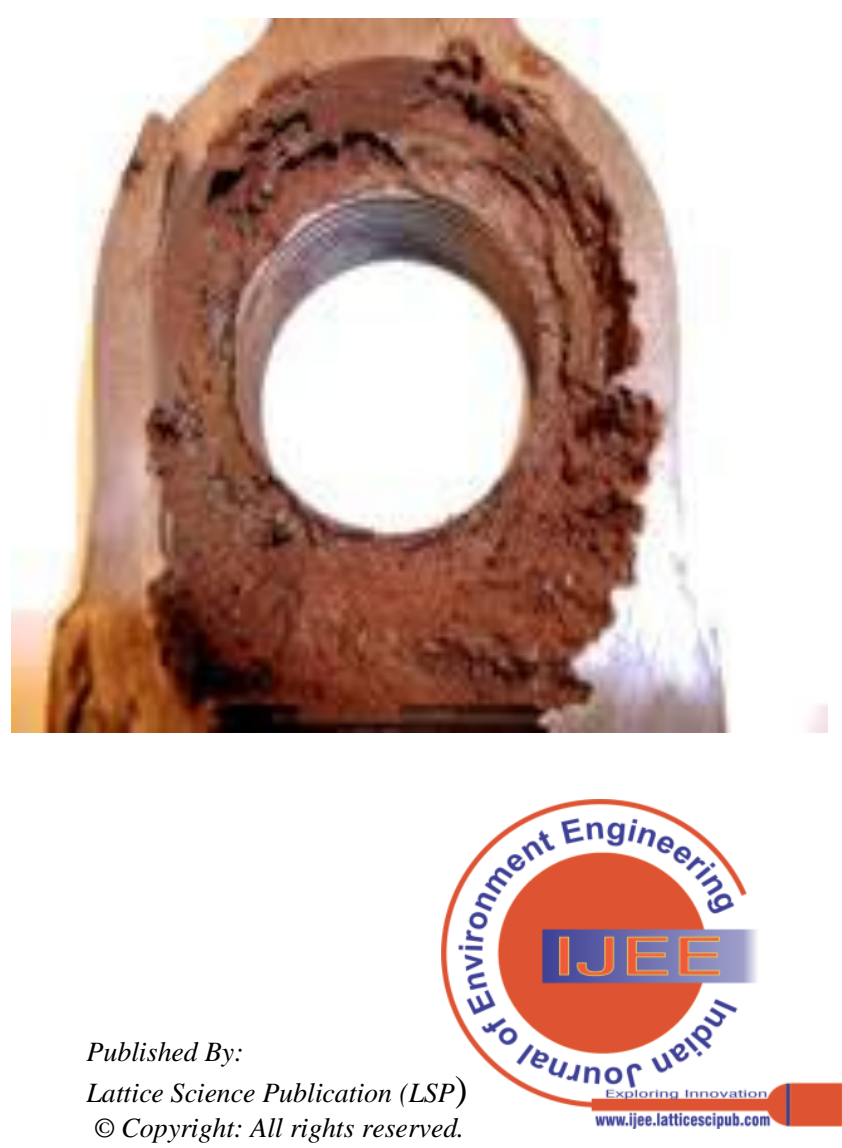


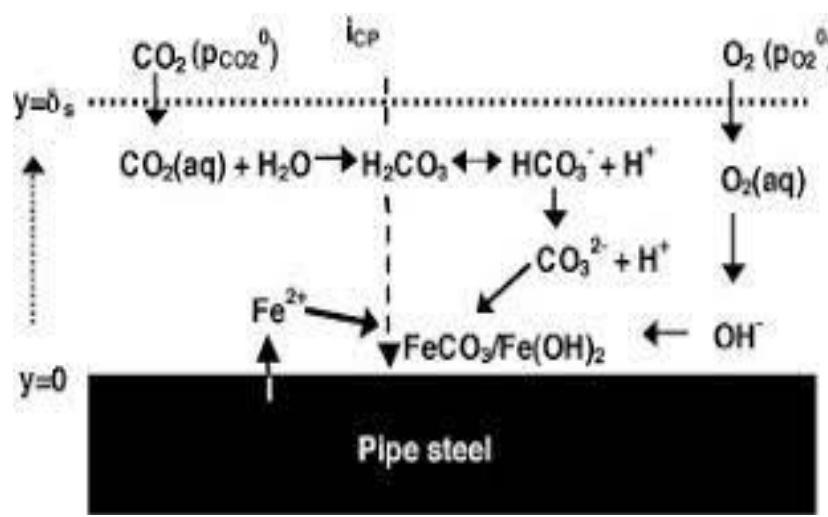

Figure 12: Instance of CO2 Corrosion (lenntech.com and sciencedirect.com)

\section{Controlling Corrosion}

1. Application of protective coatings to metal surfaces to act as a barrier or perhaps provide sacrificial protection.

2. The addition of chemical speciesof inhibitors to the environment to inhibit corrosion, alteration of an alloy chemistry to make it more resistant to corrosion (Baojun, 2021).

3. The treatment of the surface of a metal to increase its resistance to corrosion (Barbara and Robert, 2006).

4. Adequate corrosion monitoring and inspection (Kjell, 2021).

5. Cathodic protection technique (Zaki, 2006).

Selection of appropriate materials (Popoola et al., 2013).

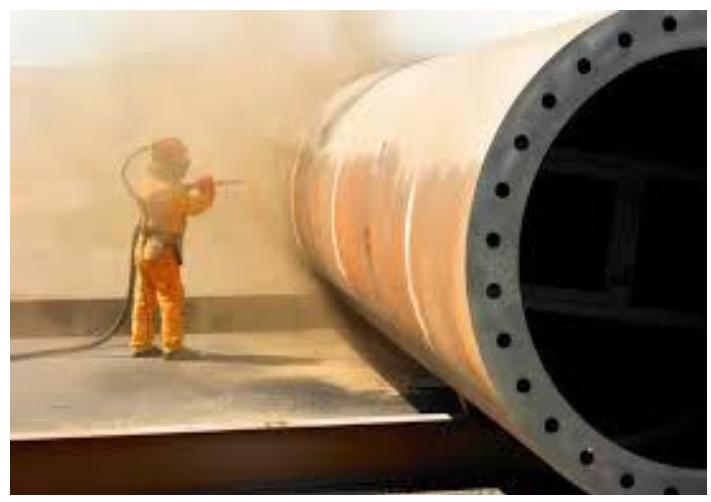

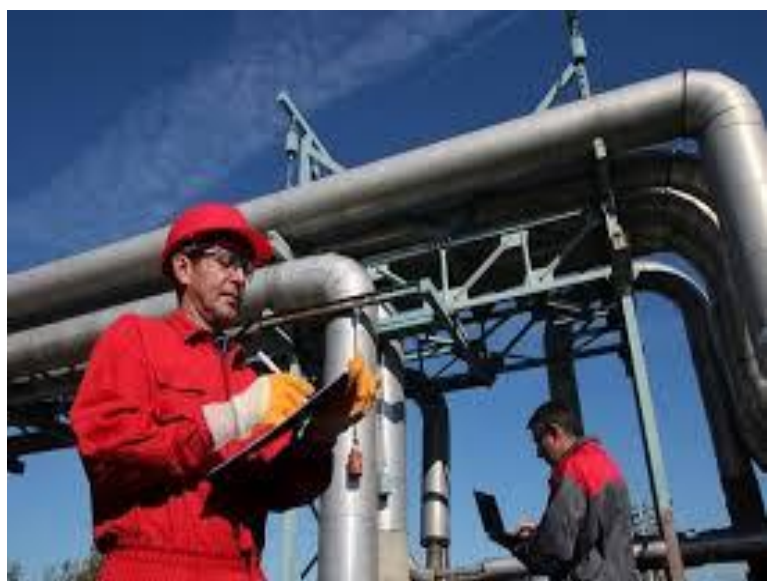

Figure 13: corrosion control and painting and monitoring (capex.com.ng and corrosionpedia.com).

\section{Corrosion Rate}

Corrosion rate is corrosion loss (the loss of the amount) of metal per unit time (year). It speeds up by impurities in the atmosphere, i.e. dissolution of metallic material in water (vaporized or condensed) and by dirt or dust which settles on metallic surfaces.

Corrosion Rate of Coupon (Mils per year penetration) =

(Weight Loss in grams) * (22300)

$$
A * d t
$$

Where A is the area of coupon (Sq. in) and dt is change in time (year) (Moural et al., 2008).

Table 1: Recommended Materials in the Oil and Gas industry

\begin{tabular}{|l|l|}
\hline Material specification & Oil and gas application \\
\hline $\begin{array}{l}\text { 1. Nickel-iron (incolys) - Alloys of Ni-Fe-Cr } \\
\text { 2. Low- and medium-alloy steels } \\
\text { 3. Nickel-chrome (inconels) - alloys of Ni-Cr-Fe }\end{array}$ & $\begin{array}{l}\text { Used in flow lines, manifolds, wellheads, liners, hangers } \\
\text { and production tubings that possesses high temperature and } \\
\text { sour application }\end{array}$ \\
\hline Nickel steels between $(2.5-9 \%)$ Ni. & $\begin{array}{l}\text { Used in pipings, pumps and storage tanks of liquefied } \\
\text { natural gas }\end{array}$ \\
\hline Straight chromium steels between (12 - 18\%) Cr. & $\begin{array}{l}\text { Used in casing pipes, wellheads Christmas trees, valves and } \\
\text { downhole rods. }\end{array}$ \\
\hline $\begin{array}{l}\text { Duplex stainless steels for: } \\
\text { 1. } 22 \% \text { chromium duplex, }\end{array}$ & $\begin{array}{l}\text { Used where extreme the level of chlorides is active like } \\
\text { pipings, internals of tanks and vessel. }\end{array}$ \\
$2 . \quad 25 \%$ chromium super - duplex) (Falkland et al., 2011) & \\
\hline
\end{tabular}

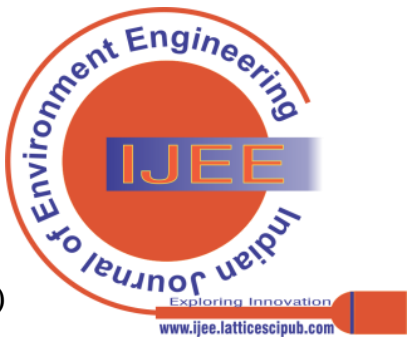




\begin{tabular}{|l|l|}
\hline Carbon steels & $\begin{array}{l}\text { Used in pipelines of petroleum, injection lines of water and } \\
\text { steam, KO drums, storage tanks, flowlines, test separators } \\
\text { and production separators }\end{array}$ \\
(Costica, Diana and Nicanor, 2021). & $\begin{array}{l}\text { Used where the level of chlorides is low, i.e. accessories } \\
\text { and equipment of separators and tanks . } \\
\text { Chromium-nickel steels }\end{array}$ \\
\hline
\end{tabular}

(Popoola et al., 2013)

* Where KO mean knock out, LNG - liquefied natural gas.

\section{LITERATURE REVIEW}

The overall yearly cost of corrosion in the Petroleum production industry is estimated to be US\$1,372 billion, broken down into $\$ 589$ million in surface pipeline and facility costs, \$463 million yearly in downhole tubing expenses, and another $\$ 320$ million in capital expenditures associated to corrosion (Simmons, 2008). The most prevalent form of corrosion in the petroleum industry happens when steel comes in contact with an aqueous medium environment and rusts (Corbin and Willson, 2007). Corrosion that is flow-induced are connected to velocities of high-flow and turbulence. Also, local turbulence can be produced by pits and mesa attack zones with particular geometries. This turbulence, in return, may damage the protective scales that exist and also prevent fresh formation on the exposed metallic surface (TERESA, 2013). Other catastrophic incidences resulting from corrosion failure had been historically recorded. (Popoola et al., 2013). The control for corrosion $\mathrm{CO}_{2}$ corrosion has been performed by common techniques such as inhibitor injection, use of corrosion resistance alloy and plastic resin coating (Masakatsu, Hideki and Perry, 2000). Acid-corrosion results from air-oxidation of iron (II) in the anode paths, in the absence of $\mathrm{OH}^{-}$ions which results in strongly acidic solutions with $\mathrm{pH}$ of 1.41(Tamura, 2008). Currently, there is a very high emphasis on the development of advanced and workable coatings for corrosion protection in various applications oftechnological (Montemor, 2014).

\section{MATERIAL AND METHODS}

This study targets the mechanism of the different types of corrosion that occur in well of oil and gas production, since this has been a deleterious happens continuously. The review method was applied in this paper.

\section{DATA AND METHODOLOGY}

\section{Data Review and Analysis}

Table 2: Experimental data taken from Nesic and Lee, 2003 illustrating the experimentally measured corrosion rates showing the effect of formation protective scale using the test conditions of temperature at $800 \mathrm{C}$, $\mathrm{pH}$ of 6.6, Partial pressure of $\mathrm{CO} 2$ of $0.54 \mathrm{bar}$, Concentration of Fe2+ of 250ppm and Speed of $1 \mathrm{~m} / \mathrm{s}$.

\begin{tabular}{|l|l|}
\hline $\begin{array}{l}\text { Corrosion rate } \\
\text { (mm/year) }\end{array}$ & Time (hour) \\
\hline 1.9 & 0 \\
\hline 1.8 & 0.1 \\
\hline 0.9 & 1 \\
\hline 1.7 & 2 \\
\hline 0.4 & 3 \\
\hline
\end{tabular}

\begin{tabular}{|l|l|}
\hline 0.3 & 5 \\
\hline 0.1 & 6 \\
\hline 0.05 & 7 \\
\hline 0.03 & 8 \\
\hline 0.03 & 9 \\
\hline 0.03 & 10 \\
\hline Regression & 0.9475 \\
\hline
\end{tabular}

\section{CORROSION RATE VERSUS TIME}

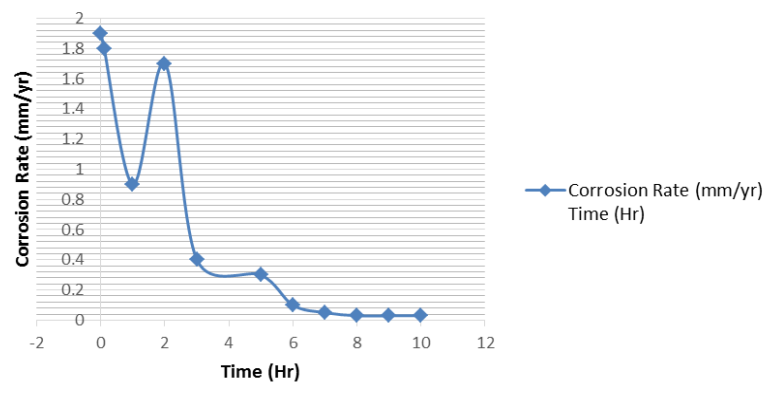

Figure 14: Corrosion rate versus Time

Table 3: Data taken from Wang, George and Nesic, 2004 illustrating the experimentally measured corrosion rates showing the effect of temperature using the test conditions of $\mathrm{pH}$ of 4, Partial pressure of $\mathrm{CO}_{2}$ of $1 \mathrm{bar}$, Concentration of $\mathrm{Fe}^{2+}$ is less than 5pm, Speed of $0.5 \mathrm{~m} / \mathrm{s}$ (Considering acetic species of 100ppm).

\begin{tabular}{|l|l|}
\hline CORROSION RATE (MM/YR) & PH \\
\hline 2.5 & 4 \\
\hline 1 & 5 \\
\hline 0.8 & 6 \\
\hline Regression & 0.8902 \\
\hline
\end{tabular}

\section{CORROSION RATE VERSUS PH}

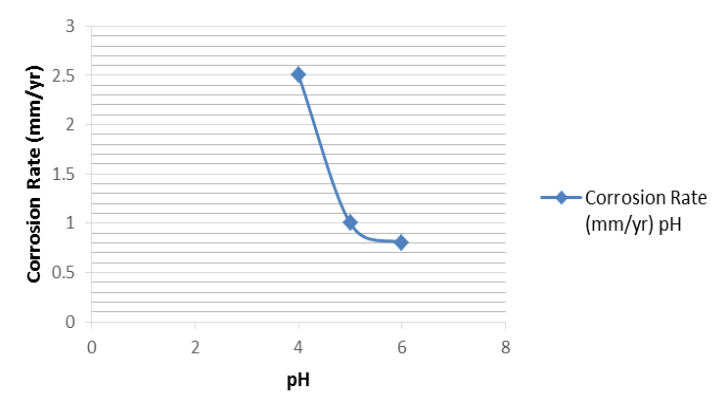

Figure 15: Corrosion rate versus $\mathbf{p H}$

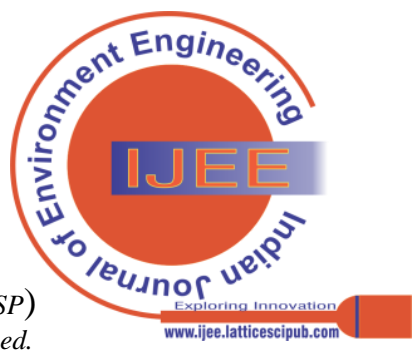


Table 4: Data taken from Wang, George and Nesic, 2004 illustrating the experimentally measured corrosion rates showing the effect of the partial pressure of $\mathrm{CO} 2$ using the test conditions of temeprature at $60 \mathrm{C}, \mathrm{pH}$ of 5 and Speed of $1 \mathrm{~m} / \mathrm{s}$.

\begin{tabular}{|l|l|}
\hline $\begin{array}{c}\text { CORROSION RATE } \\
\text { (MM/YEAR) }\end{array}$ & $\begin{array}{c}\text { CO } 2 \text { PARTIAL } \\
\text { PRESSURE (BAR) }\end{array}$ \\
\hline 8 & 3 \\
\hline 20 & 10 \\
\hline 30 & 20 \\
\hline Regression & 0.9897 \\
\hline
\end{tabular}

\section{CORROSION RATE VERSUS $\mathrm{CO}_{2}$ PARTIAL PRESSURE}

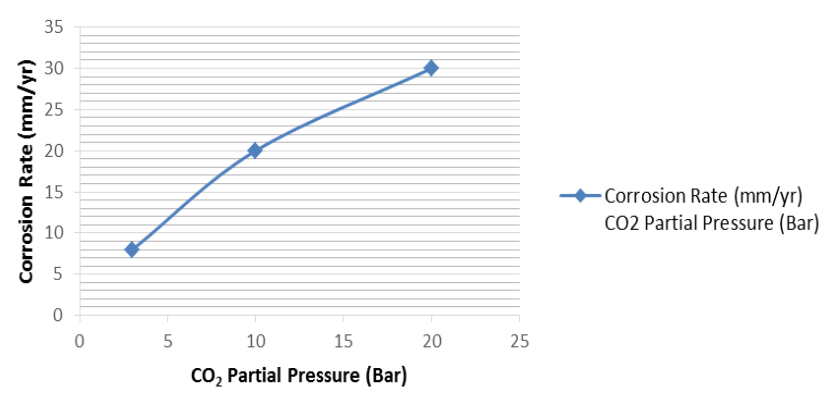

Figure 16: Corrosion rate versus CO2 Partial Pressure

Table 5: Data taken from Nesic, Solvi and Enerhaug, 1995 illustrating the experimentally measured corrosion rates showing the effect of speed in the absence of the scale of iron carbonate using test conditions of temperature at 20oC, Partial Pressure of CO2 = 1bar, Concentration of Fe2+ is less than 2ppm.

\begin{tabular}{|l|l|}
\hline CORROSION RATE (MM/YEAR) & SPEED (M/S) \\
\hline 1 & 1 \\
\hline 1.3 & 2 \\
\hline 2.2 & 4 \\
\hline 3 & 6 \\
\hline 3.2 & 10 \\
\hline Regression & 0.9517 \\
\hline
\end{tabular}

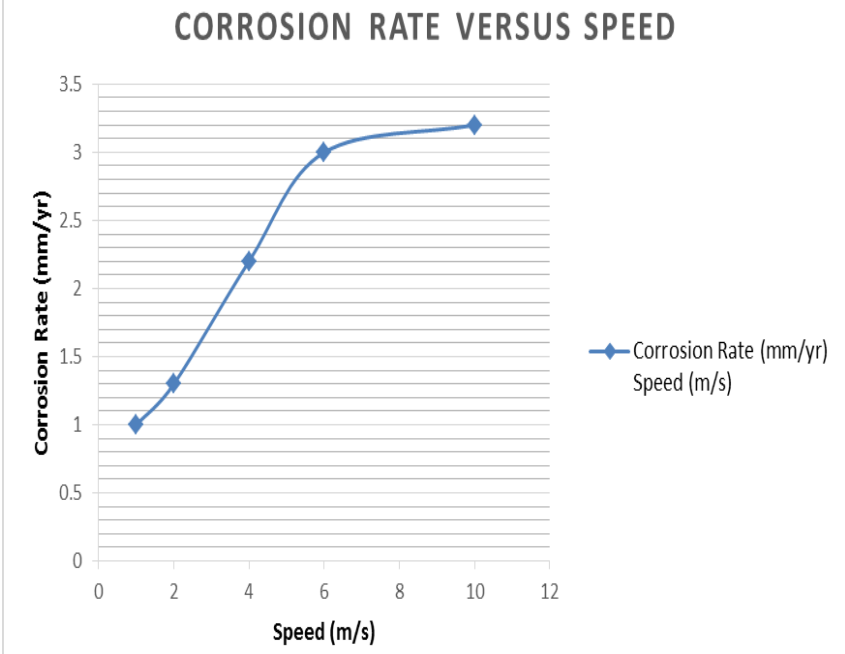

Figure 17: Corrosion rate versus Speed
Table 6: Data taken from George, Nesic and deWaard, 2004 illustrating the experimentally measured corrosion rates showing the effect of acetic acid using test conditions of temperature at $60^{\circ} \mathrm{C}, \mathrm{pH}$ of 4 , and Speed of $0.5 \mathrm{~m} / \mathrm{s}$.

\begin{tabular}{|l|l|}
\hline $\begin{array}{l}\text { Corrosion } \\
\text { (mm/year) }\end{array}$ & Rate \\
\hline 5 & Acetic Acid \\
\hline 10 & 0 \\
\hline 10 & 10 \\
\hline Regression & 0.3324 \\
\hline
\end{tabular}

\section{CORROSION RATE VERSUS CONCENTRATION} OF ACETIC ACID

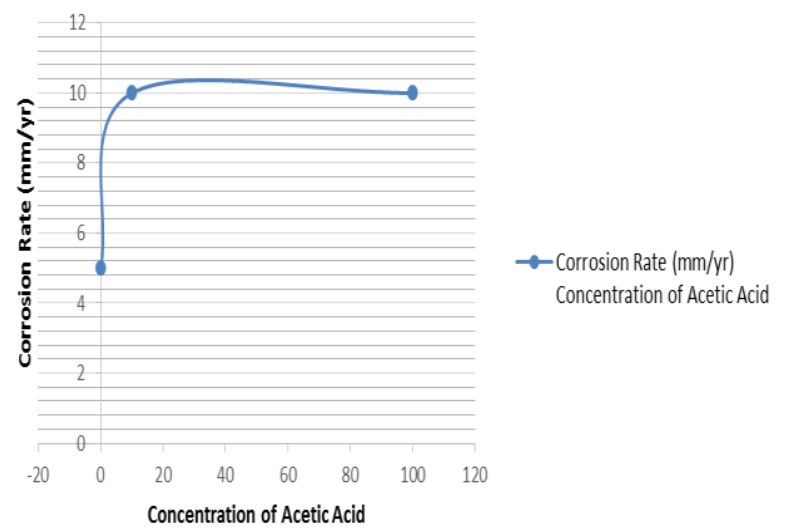

Figure 7: Corrosion rate versus Concentration of acetic acid

Table 8: Summary of Regression Results for all parameter plotted against Corrosion Rate

\begin{tabular}{|c|c|c|c|}
\hline S/No. & $\begin{array}{ll}\text { Corrosion } & \text { Rate } \\
\text { (Mm/Year) } & \end{array}$ & $\begin{array}{l}\text { Regression } \\
\left(\mathbf{R}^{2}\right)\end{array}$ & Equations \\
\hline 1. & Versus Time (Hour) & 0.9475 & $y=1.9992 e^{-0.468 x}$ \\
\hline 2. & Versus pH & 0.8902 & $y=21.75 e^{-0.57 x}$ \\
\hline 3 & $\begin{array}{l}\text { Versus } \mathrm{Co}_{2} \text { Partial } \\
\text { Pressure (Bar) }\end{array}$ & 0.9897 & $\begin{array}{l}y=11.415 \ln (x)- \\
5.0076\end{array}$ \\
\hline 4 & Versus Speed (m/s) & 0.9517 & $\begin{array}{l}\mathrm{y}=1.0581 \ln (\mathrm{x}) \\
+0.8335\end{array}$ \\
\hline 5 & $\begin{array}{l}\text { Versus Acetic Acid } \\
\text { Concentration }\end{array}$ & 0.3324 & $\begin{array}{l}\mathrm{y}=0.0302 \mathrm{x}+ \\
7.2253\end{array}$ \\
\hline
\end{tabular}

\section{RESULTS AND DISCUSSION}

In figure 14, the corrosion rate was considered against time. The corrosion rate down-surged with time from onset of $1.9 \mathrm{~mm} / \mathrm{yr}$ to $0.9 \mathrm{~mm} / \mathrm{yr}$ for 1.5 hours. This value increased again and ran up to $1.7 \mathrm{~mm} / \mathrm{yr}$ for another 0.5 years. This subsequently fell straight to $0.4 \mathrm{~mm} / \mathrm{yr}$ for 1 hour. There was a slight increase to $0.3 \mathrm{~mm} / \mathrm{yr}$ another 1 hour. The trend later continued to nose-dive until corrosion rate disappeared totally.

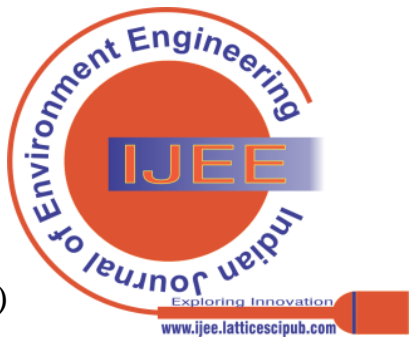


In figure 15, the corrosion rate was considered against $\mathrm{pH}$. The corrosion rate nose-dived proportionally from $2.5 \mathrm{~mm} / \mathrm{yr}$ to $1.0 \mathrm{~mm} / \mathrm{yr}$ in the acidic medium of 4 to 5 . This curved up closely to a neutral point of 6 medium values.

In figure 16, the corrosion rate was considered against $\mathrm{Co}_{2}$ partial pressure. The corrosion rate sky-rocketed proportionally from $9 \mathrm{~mm} / \mathrm{yr}$ to $20 \mathrm{~mm} / \mathrm{yr}$ with 2.5 bar to 10 bar. This further trend till 30mm/year for another 10 bar.

In figure 17, the corrosion rate was considered against speed. The corrosion rate rose very fast proportionately from $1 \mathrm{~mm} / \mathrm{yr}$ to $3 \mathrm{~mm} / \mathrm{yr}$ for speed of $1 \mathrm{~m} / \mathrm{s}$ to $6 \mathrm{~m} / \mathrm{s}$. This further increased till $3.2 \mathrm{~mm} / \mathrm{yr}$ for another $4 \mathrm{~m} / \mathrm{s}$.

In figure 18, the corrosion rate was considered against the concentration of acetic acid. The corrosion rate lapped on $0 \mathrm{~mm} / \mathrm{yr}$ for a while before nudging out to $10 \mathrm{~mm} / \mathrm{yr}$ and further decreasing to $9 \mathrm{~mm} / \mathrm{yr}$ in acetic acid concentration.

Also considering table 8, the correlation regression portends threatened conditions from corrosion rate with time. The conditions worsen considering $\mathrm{pH}$ conditions and the imposed partial pressure of $\mathrm{CO}_{2}$. It is also observed that the corrosion rate was also very fast.

\section{CONCLUSION AND RECOMMENDATION}

Since corrosion is aggressive in all the selected conditions, there is need for rapid arrest before it goes from been destructive to becoming unmanageable and a disaster. The corrosion control suggested in this paper can be adopted.

\section{REFERENCES}

1. Baojun D. (2021): Major corrosion influence factors analysis in the production well of

2. $\mathrm{CO}_{2}$ flooding and the optimization of relative anti-corrosion measures, Researchgate.

3. Barbara A. S. and Robert G. K. (2006): What is Corrosion? The Electrochemical

4. Society Interface; Page 24 - 26.

5. Corbin D, Willson E (2007): New technology for real-time corrosion detection. Tri-

6. service corrosion conference, USA Dugstad A. (1992): The importance of $\mathrm{FeCO}_{3}$ supersaturation on the $\mathrm{CO}_{2}$ corrosion of carbon steels, corrosion 92, paper 14. NACE, Houston.

7. Costica B., Diana P.B.N. and Nicanor C.(2021): Immersion Behavior of Carbon

8. Steel, Phosphate Carbon Steel and Phosphate and Painted Carbon Steel in Saltwater,

9. Researchgate.

10. George K., Nesic S., deWaard C., (2004): Electrochemical investigation and

11. modelling of $\mathrm{CO}_{2}$ corrosion of mild steel in the presence of acetic acid, Corrosion, paper no. 379 (Houston, TX: NACE International.

12. Falkland et al. (2011): Uhlig's Corrosion Handbook, Third Edition, Duplex Stainless

13. Steels, Researchgate.

14. Moural V.S. et al. (2008): Influence of microstructure on the corrosion resistance of

15. the duplex stainless steel UNS S31803, Elsevier, Volume 59, Issue 8, Pages 1127-1132.

16. Popoola et al. (2013): Corrosion problems during oil and gas production and its [CrossRef]

17. mitigation; International Journal of Industrial Chemistry, 4:35

18. Kermani M.B., Smith L.M. (1997): CO2 corrosion control in oil and gas production -

19. design considerations. The Institute of Materials, European Federation of Corrosion Publications, London.

20. Kjell W. (2021): Corrosion monitoring in refineries, Techniques for Corrosion

21. Monitoring, Researchgate.

22. Masakatsu U., Hideki T. and Perry Ian N.( 2000): The Development and
23. Implementation of a New Alloyed Steel for Oil and Gas Production Wells, NACE-00154.

24. Tamura H.(2008): The role of rusts in corrosion and corrosion protection of iron and [CrossRef]

25. steel; Volume 50, Issue 7, Elsevier, Pages 1872-1883.

26. Montemor M.F. (2014): Functional and smart coatings for corrosion protection - A [CrossRef $]$

27. review of recent advances, Surface and Coatings Technology; Volume 258, Pages 17-37.

28. Nesic et al. (2003): A mechanistic model for $\mathrm{CO}_{2}$ corrosion of mild steel in the

29. presence of protective iron carbonate scales - Scale growth model, Corrosion 59, 616. [CrossRef]

30. Roberge P.R. (2000): Handbook of corrosion engineering. McGrawHill, New York.

31. Simmons M.R. (2008): Report of Offshore Technology Conference (OTC)

32. presentation (Houston, TX: NACE International Oil and Gas Production.

33. Teresa E. P. (2013): Corrosion in the Oil and Gas Industry - An Increasing Challenge

34. for Materials; JOM, Vol. 65, No. 8.

35. Wang S., George K., Nesic S. (2004): High pressure $\mathrm{CO}_{2}$ corrosion electrochemistry

36. and the effect of acetic acid, CORROSION, paper no. 375 , NACE International.

37. Weeter RF (1965) Desorption of oxygen from water using natural gas for counter-[CrossRef]

38. current stripping. J Petrol Technology 17(5):51.

39. Zaki A.(2006): Principles of Corrosion Engineering and Corrosion Control, Cathodic

40. Protection, Researchgate.

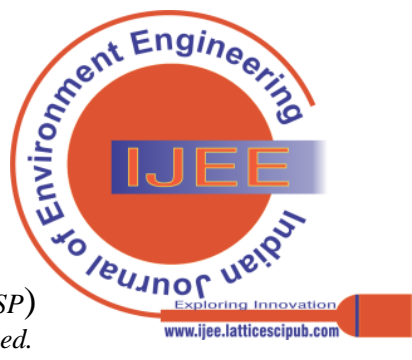

